\title{
Solving the problem of infertility among Christians: A bioethical appraisal
}

\author{
Rev. Emeka C. Ekeke and Dr. Christian O. Uchegbue \\ University of Calabar, Calabar, Nigeria \\ Email: revekekemekus@yahoo.com, Phone: +2340837930856
}

\begin{abstract}
Infertility has become a terrible cankerworm destroying the joy of many couples the world over. Among Christians, this issue has grown to a monumental level so that many Christian couples question God's power and ability. Today many Christian couples could do anything either good or bad to have children. This paper therefore examines some of the various biomedical approaches through which the problem of infertility could be solved among Christians such as artificial womb, artificial insemination, surrogacy, in-vitro fertilization and sperm and egg donation. The paper recommends, among others, that every Christian couple should know that God is the giver of children and look up to Him for direction and not plunge themselves into acts that they will regret about in the future.
\end{abstract}

Keywords: Infertility, artificial, womb, Christians, surrogacy

\section{INTRODUCTION}

The issue of infertility or barrenness among couples has become a critical problem today in the world. The growth of infertility has led biotechnology researchers into trying some new things to solve this problem. This is why the idea of artificial womb, which formerly existed in fiction, is now becoming a reality. The practice of artificial insemination is now the order of the day in many clinics and hospitals in many countries such as United Kingdom, United States of America, New Zealand, Germany, Norway, India, Nigeria, South Africa and so many other countries. The issue of surrogacy has not abated despite so many critical issues surrounding it such as the idea of depersonalizing reproduction by creating "a separation of genetic, gestational, and social parenthood" (Meinke, 2001: 2). Surrogacy has also created a problem of benefit. This means that there is a change of motive in having children, not for their (children) sake, but for another's benefit. The issue of sperm and eggs donation to solve the problem of infertility remains a critical problem especially among Christian bioethical scholars. In this paper, our intention is to carefully analyze all these issues, showing their benefits and problems and why they should either continue to flourish or should be abated especially among Christians.

Artificial Womb or Uterus: In the field of ectogenesis, an artificial womb or uterus is a mechanism that is used to grow an embryo outside of the body of a female organism that would normally internally carry the embryo to term (Wikipedia, the free encyclopedia 2009, "Artificial uterus" p.1). In some cases, artificial womb serves as a replacement organ, which could be used to assist women with damaged or diseased womb to be able to conceive to term. It is believed by researchers that since the uterus is grown from the woman's own endometrial cells (the mucous membrane lining the uterus, which becomes aggressively thicker and more glandular and has an increased blood supply in the latter part of the menstrual cycle) there would be minimal chance of organ rejection. This prepares the endometrium for implantation of the embryo, but if this does not occur much of the endometrium breaks down and is lost during menstruation. If pregnancy is established, the endometrium (the membrane lining the womb) becomes the decidual, which is shed after birth.

This idea of an artificial womb first existed in science fiction like the one depicted by Aldous Huxley in his 1932 novel, Brave New World. Huxley saw in the future where children are grown in artificial wombs before being decanted into the world. A similar scenario is portrayed in Logan's Run, where embryos are extracted from impregnated women to be grown in Maccano-breeder by a computer-controlled lifesupport system. These and many more fictions became the foundation for the research to see the workability of having an artificial womb (Wikipedia..., 2009 "Artificial uterus" p.2).

Reynolds (2005-2009) narrates how the first primary research into the engineering of an artificial uterus was conducted by Dr. Hung-Ching Liu at the Cornell University Center for Reproductive medicine and infertility. She and her team observed that a fetus 
lives in the world of bubbles. It was this observation that led her into being convinced that a baby might actually be grown outside of the mother's womb. Dr. Liu and her team, at the beginning of 2001, in Manhattan Laboratory in Cornell University's Centre for Reproductive Medicine and Infertility, "started growing sheets of human tissue composed of cells from the endometrium, the lining of the uterus. This engineered tissue, which used starter cells donated by infertile women with layer of endometrial cells is, after all, the ideal platform on which to nurture an embryo" (Reynolds, 2005-2009: 1). When Dr. Liu planted an embryo in the artificial womb, she discovered that the embryo correctly implanted into the artificial uterus' lining and started to grow. Her experiment was rather halted after six days so that it will not go beyond the legal limit permitted for research in United States.

Klass (1996) of the New York Times argues that the artificial womb exist in many countries of the world though not necessarily for human fetus. He narrates that,

In Tokyo, [Japan], researchers have developed a technique called EUFI- extrauterine fetal incubation. They have taken goat fetuses, threaded catheters through the large vessels in the umbilical cord and supplied the fetuses with oxygenated blood while suspending them in incubators that contain artificial amniotic fluid heated to body temperature (Klass, 1996: 1).

This was done by a Japanese gynecologist Professor Yoshinori Kuwabara, who created a completely artificial womb and sustained goat fetuses for several weeks.

These information show that the issue of artificial womb is no longer a fiction but researchers are working very hard to achieve a perfect example. The issue now remains; are there any ethical issues to consider? Who will benefit from this project? Of what importance will artificial womb be for the religious bodies, especially Christianity? Is there any problem artificial womb will help in solving? Is the infertility problem not enough for one to accept artificial womb?

Researchers into this artificial womb project have advanced so many reasons behind it. Some of these reasons stress its benefit to the fetus and the mother, and reduction on abortion and cloning. One issue we must stress here is that when biomedical ethical issues are discussed,
We are not talking about philosophic ethics. We are not talking about the theories of ethics or the principles of ethics. But we are, in a very real sense, talking about narratives, about stories, about ethical concerns as they deal with the lives of people, because these are what make it biomedical ethics. These are what make it clinical. These are what make it usefully meaningful (Elkins, 1995: 145).

Knowing that bioethics is not about theories, we shall be explaining on who benefits and what is benefited from artificial womb.

The Fetus: Many scholars who advocate for artificial womb argue that it will drastically reduce the death of premature infants since the fetus could be transferred to an artificial womb where it will continue to grow and develop in safety.

Others argue that the artificial womb will be safer than the mother's womb because the various risks of disease, miscarriages, drugs problem, pollutants genetic disorders and inadequate nutrition would be completely eliminated (Artificial Wombs: The End of Natural Motherhood? 2009: 1). One issue they have not been able to answer is the question of the baby's environment, which is supposed to be natural. How then will the baby associate or relate with the mother's heart beat which will not be in existence? What about the mother's actions as she moves about? This means that the baby developed in an artificial womb will not in the real sense benefit because the fetus will completely be detached from the natural and will have no bond with the mother. It will be a machine baby and will surely suffer from social and psychological disadvantages. From the Christian point of view, the womb is a place of creation or procreation. This is what the Psalmist means when he says "My substance was not hid from thee, when I was made in secret, and curiously wrought in the lowest parts of the earth" (Psalm 139:15 KJV). That fetus produced in artificial womb will be a negation of God's original intention of women bearing children. This process if advanced will produce a social nuisance who will rather not reason from human point of view, being that they were machine products.

The Mother: Scholars and researchers into artificial womb also believe that the mother will be helped by this technology. Citing the problem of damaged womb, these scholars argue that this mother instead of hiring a surrogate mother will go straight to the "womb-bank" and produce her babies. It would also 
reduce the chances of miscarriage and premature births.

Others have argued for the convenience of the mother stressing that it will save the woman the stress of "having a child without enduring more months of weight gain, sickness, health problem, and of course, labor itself, sounds awfully tempting" (Artificial Womb: The End..., 2009: 1). One important fact against this idea is that it will increase the production of contraception that will completely sever the natural womb from many women giving them freedom to sexual immorality. Secondly, it will also make employers require women to use artificial wombs to have children in order to prevent them from not being present in their work places. This will therefore make natural motherhood become a luxury, which most employers will stop supporting through the maternity leave.

Thirdly, these mothers who will use artificial womb for the production of their babies will end up having babies they are not attached to in anyway. These babies will rather look like commodities to these mothers. Just as Isaiah 49:15 says, these mothers will forget their sucking children because they are not bonded with them. Aside from the aforementioned, it negates God's original intention for human being to be the means of pro-creation not machine.

Abortion, they argue that artificial womb will reduce the tendency to abortion, since the woman is free to have children through artificial womb. Though this may be true, the fact still remains that it may not be every woman that will be able to afford artificial womb because it will be very exorbitant. This means that abortion, which has remained very high among teenagers, will not really abate as a result of artificial womb.

It would reduce cloning. These pro-artificial researchers and other bio-ethicists argue that artificial womb will reduce the tendency to cloning. They believe that it will become easier for gays not simply to have children, but to have their own children. We argue here that from the Christian point of view gay is sin against God and so any project that is aimed at supporting it or encouraging it should be fully discarded.

Looking at the scripture, our conclusion on ethical matters of artificial womb is that it is against God's original intention of procreation. It questions God's authority over man and supports the secular humanists view that man is the lord of himself and so can use his life the way he likes. Artificial womb, if allowed to fully develop, will adulterate the human race with the production of beings not born in the natural way. This will surely become a social nuisance to the society. These researchers therefore advocate that its research should be banned and not allowed to progress

Artificial Insemination: This is the process by which sperm is placed into the reproductive track of a female for the purpose of impregnating the female by using means other than sexual intercourse. Wikipedia... (2005) explains that it is used as assisted reproductive technology primarily to treat infertility but is now being increasingly used to enable women without a male partner (that is single women and lesbians) to become pregnant and to produce children by using sperm provided by a sperm donor ("Artificial Insemination" p.1). It is a believed and accepted fact that the woman is the gestational and genetic mother of the child produced while the sperm donor is the genetic or biological father of the child. Modern techniques for human artificial insemination were first developed for the diary cattle to allow many cows to be impregnated with the sperm of a bull with traits for improved milk production.

There are many types of artificial insemination which includes intravaginal insemination (where sperms are deposited in the woman's vagina by artificial means other than through intercourse), intracervical insemination, intrauterine insemination and intraFallopian insemination (a process where sperms are deposited or placed inside the pelvis near the mouth of the Fallopian tube). Today the most commonly used techniques are intrauterine insemination (IUI) where the sperm is deposited directly in the female uterus, followed by intracervical insemination $(\mathrm{ICI})$ where the sperm is placed in the cervix by artificial means.

As we try to expatiate on this technique, a careful look shall be made of the necessity for it, the preparation for it, its procedure and techniques and the sperm donor. Finally the ethical issues surrounding it shall be discussed.

The Necessity for Artificial Insemination: In this modern and technological world, the problem of infertility has to be fought to a stand still. This is the main trust of its use. It helps wives to conceive who were having serious problem of conception. NHS Choices (2009) argues that artificial insemination can be useful in helping couples to conceive where:

There is a problem with the man's sperm, or he cannot produce sperm during sexual intercourse; 
there is no obvious reason why the couple cannot conceive a child (unexplained infertility), or the woman has minimal to mild endometriosis. This is a condition where cells that are usually only found in the lining of the uterus (womb) begin to grow in other parts of the reproductive system, which can be a cause of infertility (p.1).

There are still more reasons why artificial insemination is necessary. These include

Men who are unable to ejaculate inside their wives vagina for whatever reasons.... Causes for ejaculation failure include diabetes, multiple sclerosis, spinal cord injury and retrograde ejaculation, where sperm are released backward into the bladder instead of urethra. Retrograde ejaculation may be due to diabetes, trauma, or operation in the bladder neck or a side effect of certain drugs. Men with mildly low sperm count, poor quality sperm or antisperm antibodies. Men who wish to freeze their sperm for possible future use before vasectomy, chemotherapy or radiotherapy for cancer. Women with cervical mucus hostility or poor cervical mucus. Some infertility clinics may offer intrauterine insemination of a HIV negative woman with washed and prepared sperm of her HIV positive husband partner (Artificial Insemination, 2005: 1).

Women in same-partnership (lesbians) have also used artificial insemination as a way of conceiving a child since they reject any relationship with males.

\section{Preparation and Procurement for Sperm Donation} and Insemination: In preparing for this insemination, the first preparation is to get a healthy sperm that will be used in the process. This may be either the husband's sperm or sperm provided by a known or anonymous donor.

Sperm provided by an anonymous donor is done through masturbation and the sperm is stored and frozen in a sperm bank. In some cases it might not be masturbation but through the use of an electric stimulator and in this case, the semen is collected during intercourse through the use of a special condom. (Wikipedia... 2009, "Artificial Insemination" p.1, 2). The woman's menstrual cycle during this period is closely observed, "by tracking basal body temperature (BBT) and changes in vaginal mucous, or using ovulation kits, ultrasounds or blood tests" (p.2).

Adams (1988) explains that when using intrauterine insemination (IUI), "the sperm must immediately be "washed" in a laboratory and concentrated in Hams
FIO media without L-glutamine, warmed to 3YC" ( $p$ 56). The reason for the washing of the sperm is to increase the chances of fertilization by removing any mucus and non-motile (unmovable) sperm in the Semen (Wikipedia..., 2005, "Artificial insemination" p.2).

On the procedure for the insemination where intrauterine method is used, the filtered and washed sperm is brought, and this concentrated sperm is passed directly from the vagina into the woman's womb (uterus) through a tube called catheter. Semen is occasionally inserted twice within a treatment cycle. If the procedure is successful, the woman will surely conceive and carry the baby to term. Wikipedia... (2005) further explains that "a pregnancy resulting from artificial insemination is no different from any other pregnancy except that there may be a slight increased likelihood of multiple births rather than singleton babies if drugs are used by the woman for a stimulated cycle" ("Artificial insemination" p.2).

Having briefly analyzed artificial insemination, it is important that we consider some ethical issues around it. The first is the issue of extracting sperm for either storage or direct use. In most cases masturbation is used. Christians believe that masturbation is an immoral act, which tends to satisfy sexual urge through the unnatural means. When a man subjects himself to masturbation in order to produce sperm to donate to people or to be stored in a sperm bank, the question is how spiritual or moral is that individual? One will argue that he is doing services to humanity but the question is must service to humanity be done through immoral means?

Furthermore, when an anonymous sperm is used to inseminate into the woman, it is not less than adultery from the Christian point of view. The child that will be born will be a bastard, which may create problem in the family because the gene of the child will be completely different from the woman's husband's. The paternal relationship between the child and the supposed father will not be cordial. This is why the United Kingdom in 2005 changed the law regarding sperm donor anonymity. NHS Choices (2009) explains:

Any person who is born from donated sperm after April 01, 2005 is entitled to apply to the Human Fertility and Embryology Authority (HFEA) to obtain information about the identity of the donor, once they have reached 18 years of age. The HFEA is 
responsible for regulating all fertility clinics in the UK (p.2).

With the child locating his/her biological father at the age of 18, the reason for the insemination, on the part of the man, is then defeated because it means he really does not have a child.

Though artificial insemination is a good development in fighting infertility both in men and women, the procedure, when it has to do with another person's sperm and not the husband's, should not be allowed among Christians. Again, where lesbians now use this method to raise children, it is an evil which is not supposed to continue. This work therefore suggests that where artificial insemination is needed by couples (married people) who are suffering from infertility problem, they should be helped provided the sperm is the husband's but where it has to do with single mothers or lesbians it should not be accepted.

Surrogacy: Many people today are not reflecting on the happenings in the society either because they are too busy doing something or because of material prosperity. The fabric of our society which is the family values, have been so eroded that every issue that relates to anything ethics is viewed from the secular humanist relativistic point of view or from utilitarian point of view, which satisfies the highest number at the long run.

Surrogacy is another issue, which is creating a kind of uproar among governments, legal bodies, ethical institutions and religious bodies. It is one of the modern reproductive technologies that have farreaching consequences that it raises more uncountable/ innumerable ethical and legal questions than answers. Meinke (2001) explains that "it has been hotly debated in courts and legislatures, and has merited consideration by commissions, inquires, working parties and professional societies in Australia, Great Britain, France, Canada, and many more countries, as well as in the United States" (p.1). This shows that surrogacy is a cardinal issue in bioethics. Surrogacy is a practice where an arrangement is made between a woman and an infertile couple, to bear a child for them with the intent of relinquishing the infant at birth. The "surrogate agrees to be artificially inseminated with the husband's sperm, to bear a child, and at birth to give up all parental rights and transfer physical custody of the child to the commissioning couple" (Meinke, 2001: 1). There are three forms of surrogacy today:

Gestational Surrogacy: The first form is where a commissioning woman produces eggs which are than surgically harvested and fertilized in a glass dish by the husband's or a donor's sperm. The resultant embryo is then implanted into the womb or uterus of the volunteer or surrogate, who then carries it to term.

The second form is used when both husband and wife are infertile. Donated embryos will be put into the surrogate's womb in the hope that she will produce a child for the commissioning couple.

The third form is traditional surrogacy. This is the artificial insemination of the surrogate with sperm from the husband or from a donor, in which case the surrogate mother herself is the genetic mother of the child that is produced. There are some forms of surrogacy which is practiced in Africa which could be traced to Bible days. This is a situation where an infertile woman arranges a lady for the husband to raise offspring for her. This happened in the case of Abraham and Sarah where Sarah handed Hagar, her maid, to Abraham as wife to raise children for her since she was infertile. Shields (2004) explains that "when the surrogate gives birth, she hands over the baby to the couple for whom she has been acting. In some countries she is permitted to receive an exercise payment of some kind in order to compensate her for the inconvenience she experiences" (p.232). Some of the risk involved include;

1. The financial exploitation of either party by the other;

2. The surrogate mother may decide to keep the child after birth. The implication of this is that the law cannot force her to part with the child because she is bonded with the baby in her womb.

3. There may be a disruption of the surrogate mother's own family life;

4. The surrogate and her family may feel bereaved of their child when the baby is surrendered because of the bond existing between the mother and the baby in her womb;

5. In the case of a serious defect on the baby, the commissioning couple may reject the child and

6 . There is the risk of illness on the surrogate mother during pregnancy and a sense of loss if abortion (miscarriage) occurs.

There are serious ethical issues in relation to surrogate motherhood. Many have argued that "surrogate arrangement depersonalizes reproduction and creates a separation of genetic, gestational and 
social parenthood" (Meinke, 2001: 2). How will a commissioning couple inform their child how he/she was born and how do you think the child will feel? These and many of such questions are the reasons why the Catholic Church Opposes all forms of surrogacy. Their reasons include the fact that it offends the "dignity of the child, the uniqueness of the mother-child relationship, and the sanctity of marriage" (Nathaniel Centre, 2005-2009 "Surrogacy" p.1). It has also been seen that surrogacy makes women and children as commodities. This is why (Surrogacy Arrangement Act 1985) (Slip Law) in Great Britain, Chapter 49, Sections 1-5, 1985 “... establishes that no person in the United Kingdom may take part in commercial negotiations that would lead to a surrogacy arrangement; such persons are declared guilty of an offense" (p.6).

Irrespective of how meaningful, supportive and helpful surrogacy may sound to alleviate the sufferings of infertile couples, it should be clear that surrogacy does not support any biblical injunction. It is clear that conception, gestation, birth and nurturing are part of a continuum of relationship that exists between child and parent. This kind of relationship is to last for a lifetime. Surrogacy fractures that continuity of relationship and so from our point of view as Christians should be banned. When issues of surrogacy arise, societies take decisions based purely on secular humanistic grounds or the utilitarian criteria. For the Christian such criteria are not adequate bases on which to decide their rightness or wrongness. Biblical principles must be applied to such decision-making situations and his conscience before God must take precedence over any other advice he might receive. Shields (2004) opines that "Christian principles seem to dictate caution and, in most cases, a negative response. But there may nonetheless, be instances in which resort to these treatment is best left as matter for liberty of conscience" (p.236).

\section{In-Vitro Fertilisation, Sperm and Eggs Donation}

Since the first baby in the world conceived by egg donation was born in the early 1980s (Klein and Sauer 2002: 277-291), the issues of in-vitro fertilization and eggs and sperm donation have become controversial in many parts of the world. Spilker and Lie (2002) explain that "sperm donation" has been a medical practice offered by the Norwegian public health service since 1950s, and until 2003 the donors were anonymous (p.332).
In-vitro fertilization (IVF) is a medical technique developed in 1970s with the aim of helping couples that were infertile to have offspring. It is a process whereby eggs are removed surgically from the wife and fertilized by her husband's (or a donor's) sperm in a glass receptacle. The resultant embryos or some of them are returned to the wife (Shields 2004: 230). Before the extraction is done, the woman is given a drug to stimulate the production of eggs, which can then be harvested through surgical means. This stimulus drug has the potential, according to NHS Choices, of increasing the risk of experiencing multiple births (p.6). Many babies have been born through this process for couples desperately in need of children and who could not have babies through the natural means. Shields (2004: 230) argues that surplus egg and embryos can be destroyed in the process of trying to secure one and others are used for scientific experimentation or donated to other women or frozen for impregnation at a later stage, thus allowing the woman to have another child without further surgery.

So many bio-ethicists, especially those belonging to secular humanists circle, encourage in-vitro fertilization because according to them it is the end that justifies the means. It is a help to those who are desperately in need of children, so to them it should be sustained. But a careful look at it from the Christian point of view reveals that it negates God's original intention of parenting and so has serious ethical questions.

The first ethical issue is in its success rate. Shields (2004) explains that "at best the success rate has been around 20percent, and there is an increased risk of stillbirth and of genetic abnormality" (230). The above statement by Shields means that if 100 women go for in-vitro fertilization, the maximum numbers of people that will succeed with pregnancy are 20. Even among the 20 some will have stillbirth while others will have genetic abnormality. This means that the risk is so high that ethically speaking it is not worth it. Another issue is that of the cost. Shields (2004) further adds: "Treatment is expensive and beyond the reach of all but the rich" (p.230). This means that it is exclusively for the rich and wealthy in the society.

Another burning issue is the fact that this process encourages human eggs and embryos trade, and in effect, making children commercial entities. Furthermore, the fact that many embryos are wasted during the process "depriving those tiny human beings of life" (Uduigwomen, 2003: 170) in order for 
one of them to survive, is a more reason why it must be banned. This is because from a Christian point of view, life starts at conception. Therefore the fertilization of the egg in a glass tube is the beginning of that young life and any destruction of it is destruction of human life. IVF as a method of treating infertility is a wrong method because it negates the cardinal issues of Christian faith, which is the sanctity of human life.

Sperm donation is a process where men donate their sperms to sperm bank where it is stored and frozen for people who will use it at a future time. In some cases this sperm is donated by somebody the infertile couple knows who may be a relative or a friend. In the majority of cases, couples that wish to use sperm either for artificial insemination or in-vitro fertilization, go for anonymous donation. Today anonymous sperm donation is no longer the case in United Kingdom as we explained earlier. The donor's identity must be known and once the child reaches 18 years of age he could seek to know the person (NHS Choice, 2009: 2).

Egg donation has to do with surgical harvesting of eggs from a woman to be stored and frozen in an egg bank were it could be used for another pregnancy or sold to those in need or used for experimentation.

In countries like Norway, it is an offense to donate egg or store it in any kind of bank. Laqueur (1990), arguing in favor of this view, opines that "fertilization became a miniaturized version of monogamous marriage where the animalcule/husband managed to get through the simple opening of the egg/wife, which then closed" (p.172). By this statement Laqueur is of the view that eggs and sperm should not be interchanged or given to any other person who is not part of that marriage bond. If this is done, it becomes "adultery by proxy" according to Uduigwomen (2003); "and hence it is morally wrong" (170). Egg donation is therefore wrong from the Christian context because with it, the woman has to be treated with hormones, which will create problems of stillbirth, genetically abnormal babies and or multiple births. With egg donations it can be difficult to determine the difference between a biological mother and a social mother. It makes child birth a social creation and so negates God's plan. This also makes a child not to know who his/her biological mother is.

Further more, we should understand that donation of human gametes (sperm, eggs or embryos) creates real dangers for generations yet unborn. It may cause close relatives who are unaware of their genetic relationship or connection to marry each other or somehow, donate sperm or eggs to someone who may be a close relative thereby producing children or grandchildren from their own relative.

Again, there may be accidental or mischievous mixups in a laboratory where different couples carry children belonging to other couples or where a couple receives a twin that are of mixed race. This is one problem of in-vitro fertilization (test-tube babies). There will also be identity problem caused by donation of either egg or sperm to the child so conceived. He/she will not know his genetic origin. Drugs that increase hormones can also cause harm to the women.

\section{CONCLUSION:}

In concluding this paper on solving infertility problem, we should know that the issue of infertility is not a do or die affair and so should not be pursued without restraint. Shields (2004) argues that "it is not; therefore, a moral priority to use the skills of physicians to treat it. Life threatening diseases are a much greater priority" (p.234). The Scripture is filled with the fact that it is God's prerogative to give children and, in some cases, to prevent their conception and birth (c.f. Gen 16:2; 20:18; 29:31; 30:2,22; Psalm 127:3; Isaiah 44:24;49:5). The fact, as we noted earlier, that IVF produces a higher rate of infant death and of handicap in children conceived in that way, suggests that those who resort to such treatment are in some way contravening the will of God.

Anonymous insemination donation is not a levirate marriage as was practiced in the Old Testament. The levirate marriage demands that a surviving brother takes care of the late brother's widow and produces children who bear the name of the late brother. He marries her and takes care of the child or children born. The modern insemination donor does not and cannot do these things because he acts anonymously. Donating sperm, eggs or embryos removes procreation from the bedroom to the clinic thereby separating the beginning of human life from the 'one flesh' union that the Bible "puts at the very heart of marriage and of the creation of a new life" (Shields 2004: 235). This whole issue means that Christians should learn to look up onto God and get direction as per what to do in matters of infertility.

\section{REFERENCES}

Adams, R.M.D. (1988). In-vitro fertilization technique. Monterey: C. A 
Artificial Insemination. (2005). (Website: http://www.ivfinfertility.com /insemination/index.Php on March 05, 2009).

Artificial womb: The end of natural motherhood? (2009). (Website

http://atheism.About.Com/Library/FAQs/Phil/bphil_ethb io_wombs.htm on March 05, 2009).

Elkins, T. (1995). "The end of the autonomy road" in Richard D. Land \& Louis A. Moore (Eds) Life at risk: The crises in medical ethics. Nashville, Tennessee: Broadman \& Holman: 144-158

Klass, P. (1996). "The Artificial womb is born" in The New York Times. Sunday September 29

Klein, J. and Sauer, M. V. (2002). "Oocyte donation" in Best practice and research clinical obstetrics and gynecology 16(3): 277-291.

Laqueur, T. (1990). Making sex: Body and gender from the Greeks to Freud. Cambridge, M A: Harvard UP

Meinke, S. A. (2001, June). Surrogate motherhood: ethical and legal issues. Washington, D.C: National Reference Centre for Bioethics Literature

NHS Choices. (2009). "Artificial insemination". (Website: http://www.nhs.UK on April 5, 2009).
Reynolds, G. (2005, August). "Artificial wombs: Will we grow babies outside their mothers' bodies?" (Website: http://www.popsci.com/ scitech/article/200508/artificial-womb, on March 05, 2009).

Shields, N. (2004). Christian ethics. Bukuru: ACTS

Spilker, K. and Lie, M. (2007). "Gender and bioethics intertwined: Egg donation within the context of equal opportunities" in European Journal of Women's Studies (14)4 London: SAGE: 327-340

Surrogacy Arrangement Act 1985, Great Britain. Chapter 49, sections 1-5 paragraph 6.

The Nathaniel Centre. (2005-2009). "Surrogacy". Bioethical issues. (Website: http://www.nathaniel.org.nz/?sid=34 on $3 / 5 / 2009$

Uduigwomen, A. F. (2003). Contemporary issues and problems in biomedical ethics. Calabar: Vision Connections

Wikipedia, the free encyclopedia. (2009). "Artificial uterus" (Website: http://en.Wikipedia.org/wiki/Artificial-womb on January 13,2009 )

"Artificial insemination" (2008). (Website: http://en.wikipedia.org/wiki /artificial_insemination on $3 / 27 / 2009$ 